\title{
Enhancing Forest Productivity, Value, and Health through Silviculture in a Changing World
}

\author{
Nelson Thiffault ${ }^{1, *}$ and Bradley D. Pinno ${ }^{2}(\mathbb{D}$ \\ 1 Canadian Wood Fibre Centre, Canadian Forest Service, Natural Resources Canada, 1055 du P.E.P.S., \\ P.O. Box 10380, Stn. Sainte-Foy, Québec City, QC G1V 4C7, Canada \\ 2 Department of Renewable Resources, University of Alberta, 442 Earth Sciences Building, \\ Edmonton, AL T6G 2E3, Canada; bpinno@ualberta.ca \\ * Correspondence: nelson.thiffault@nrcan-rncan.gc.ca
}

check for updates

Citation: Thiffault, N.; Pinno, B.D Enhancing Forest Productivity, Value, and Health through Silviculture in a Changing World. Forests 2021, 12, 1550. https://doi.org/10.3390/ f12111550

Received: 2 November 2021

Accepted: 7 November 2021

Published: 10 November 2021

Publisher's Note: MDPI stays neutral with regard to jurisdictional claims in published maps and institutional affiliations.

Copyright: (c) 2021 by the authors. Licensee MDPI, Basel, Switzerland. This article is an open access article distributed under the terms and conditions of the Creative Commons Attribution (CC BY) license (https:/ / creativecommons.org/licenses/by/ $4.0 /)$.

\section{Introduction}

Global change is inducing important stresses to forests worldwide [1,2]. For example, increases in the frequency and intensity of drought events and invasions by new exotic invasive plants and insects have started to modify forest dynamics, including regeneration, recruitment, and growth, with significant effects on the provision of ecosystem services [3]. Meanwhile, the world population is exerting growing pressure on forest ecosystems as a source of materials supporting the transition to a low-carbon economy, e.g., [4]. Silviculture, which enables controlling the establishment, growth, composition, and quality of forest vegetation to achieve management objectives [5], offers the opportunity to create and maintain forest ecosystems that can meet these challenges [6]. There is a vibrant need to conduct and disseminate silviculture research that provides the knowledge required to favor the resistance, resilience, or transition of forest ecosystems in the face of climate change $[7,8]$.

This Special Issue of Forests focuses on the role of silviculture to enhance forest productivity, value, and health in the context of global change. It comprises nine papers describing studies conducted in the temperate deciduous and coniferous forests from the United States, Canada, and Sweden. This collection contains studies investigating various functions of silviculture (regeneration, stand tending, and harvesting) or their combinations, looking at how traditional or new treatments can help increase growth or adapt forests to climate change, and deciphering interactions between silviculture and climate, site characteristics, genetics, and biotic pressures.

\section{Summary of Papers Included in the Special Issue}

Black walnut (Juglans nigra L.) is a high-value hardwood species in the continental United States. The harvest pressure that has resulted from the high demand for this wood has caused a gradual depletion of quality trees. In this context, the production of the species under intensive plantation management scenarios is gaining significant interest. Sloan et al. [9] examined the short-term impacts and fates of urea-based enhanced efficiency fertilizers applied in intensively managed plantations of black walnut. They tested if the use of slow-release, controlled release, and stabilized $\mathrm{N}$ fertilizers applied mid-rotation can limit nutrient losses and improve plantation productivity, compared with uncoated urea and an unfertilized control. While they did not observe significant differences in fertilizer $\mathrm{N}$ recovery among treatments, their study demonstrated that competing vegetation could be a strong sink for applied $\mathrm{N}$. They concluded that the availability of applied $\mathrm{N}$ could be improved for crop trees through intensive plantation management practices involving both vegetation management and fertilization.

Broadleaved forests are becoming increasingly important in Sweden, notably due to improving growth conditions associated with climate change. Skovsgaard et al. [10] 
reported on the results from two field experiments that quantify the influence of thinning, high pruning, and slash management on crop trees and stand growth in young even-aged stands of planted silver birch (Betula pendula Roth). Their study focused on the effects of thinning and slash extraction/retention on stand volume growth and of crop tree selection, thinning, and pruning on the size and growth of individual trees. In comparison to the strictly unthinned control, their findings showed a general decline in stand-level growth with increasing thinning intensity. Even less drastic deletions, such as point thinning, slowed stand growth. However, slash extraction in heavily thinned stands did not reduce growth. With increasing thinning intensity, the development of pre-selected future crop trees increased, but pruning reduced growth with increasing pruning severity.

Over the past few decades, partial cutting practices have gained interest as alternative approaches to traditional clearcutting in boreal ecosystems. In boreal mixedwoods, in particular, partial harvest is considered a potential means of addressing the diminishing proportion of conifers to the benefit of intolerant hardwoods. Maleki et al. [11] investigated the matter and reported on a study comparing clearcutting and low-intensity partial cutting in regards to hardwood and conifer regeneration levels 7-19 years following treatments in trembling aspen (Populus tremuloides)-dominated stands of western Quebec, Canada. They observed that intolerant hardwood regeneration was positively linked with the amount of mature aspen prior to harvesting and increased with percent basal area reduction. Conifer regeneration after partial cutting was comparable to controls and higher than after clearcutting. Their findings suggest that silvicultural treatments that limit canopy opening and promote mixed forest floor litter can be used to reduce broadleaves species abundance and promote or sustain conifer regeneration in boreal mixedwoods.

In temperate deciduous forests of northern United States, concerns are arising regarding the abundant recruitment of sweet birch (Betula lenta L.) after overstory disturbances, such as windthrow and harvest. This phenomenon poses a challenge to managers in sustaining forest diversity and values, as future forests are at risk of becoming increasingly monodominant. Royo et al. [12] examined birch regeneration under contrasting treatment sequences consisting of either pre- or post-harvest herbicide application in a shelterwood system applied to hardwood-dominated stands of northern Pennsylvania, USA. The authors also used fences to investigate the potential interactions between the timing of herbicide application (pre- or post-harvest) and white-tailed deer (Odocoileus virginianus Zimmerman) browsing. Their results confirmed that the shelterwood-herbicide sequence initially limited the establishment of birch relative to the herbicide-shelterwood sequence, but that birch recruitment remained high and overtopped desirable regeneration within 5 years. Although browse pressure did affect birch growth negatively, these results indicate that follow-up vegetation management treatments are necessary to promote desirable regeneration in this context.

In Canada, wild timber stocks are nearing their end, and there is a need to increase timber productivity from managed forests to sustain the fiber supply and provisions of other ecosystem services. In their paper, Pinno et al. [13] argued that while the province of Alberta is well suited for applying such intensive silviculture, philosophies and policy decisions have limited its implementation. Using growth model projections for mixedwoods, they showed how intensive silviculture might produce merchantable stands by age 50 , compared with the normal rotation age of 80 with basic silviculture. Due to the increased growth of regenerating stands, forest-level constraints in timber flow could be removed, resulting in even more gains.

Forest vegetation management practices, which traditionally focused on promoting the growth of preferred species over non-commercial plant species, now embrace the broader objective of managing forest succession for various ecosystem services. Deighton et al. [14] compared the effects of various release treatments (aerial herbicide spray, motor-manual brushsaws, and complete competition removal via herbicides) and control treatment on plant diversity, stand-scale yield, and individual crop tree responses at two jack pine sites in Ontario, Canada. They observed that release treatments did not result in a loss of plant 
diversity over a 25 -year period but did increase stand-scale yield and individual crop tree development, with the greatest advantages happening in the more intensive release treatments. None of the treatments maximized all the indicators they studied, however, emphasizing that forest managers are faced with trade-offs when choosing vegetation management treatments. The authors stressed that other criteria and indicators not taken into account in their work, such as soil and water resource conservation and maintenance of socio-economic benefit, also need to be taken into account when making informed policy decisions and progress toward sustainable forest management.

In some jurisdictions, such as Quebec (Canada), mechanical release using motormanual brushsaws has replaced the use of chemical herbicides for forest vegetation management. While mechanical means of managing forest vegetation usually have high social acceptability, they are generally associated with high costs and difficulty in locating qualified staff. In this context, de Vriendt et al. [15] investigated if the browsing of competition by large herbivores may represent an alternative to mechanical release in a region with high moose (Alces alces L.) density and when planted seedlings are resistant to browsing. Using an experimental design consisting of pairs of moose exclosures and unfenced plots, combined with areas that received (or not) a mechanical release treatment, they observed that sapling density and basal area of competing species were reduced more effectively by moose browsing than by mechanical release. While mechanical release reduced the sapling density of taller competitors only, browsing reduced the sapling density of competitors across a greater size range and translated into a greater positive effect on the planted spruce basal area. The authors concluded that in areas where plantations of browse-resistant crop trees are common, combining wildlife management and silviculture decisions might be beneficial to both the hunting and forestry industries while providing a cost-free and socially acceptable forest vegetation management alternative.

Understanding the role that climate, site characteristics, and harvesting methods play in determining competing vegetation abundance is essential to focus vegetation monitoring and enable predicting sites where site preparation or tending operations will be required. In their study, Ménard et al. [16] aimed to identify the factors influencing the short-term abundance and composition of competing vegetation in the eastern boreal forest of Canada and to better understand the mid-term evolution of the regeneration/competing vegetation complex in cases of marginal regeneration conditions. The analyses of data from operational surveys conducted about 5 years post-harvest, as well as data originating from a remeasurement of a portion of the sites, showed that the abundance and composition of competing vegetation were closely linked to broad ecosystem characteristics included in ecological classification systems, which thus constitute a promising framework to plan efforts in competing vegetation management. Their results show that efforts and resources invested in post-harvest regeneration inventories can be targeted to critical sites based on known and spatially explicit a priori information.

Some regions of the boreal forests are prone to paludification. This process consists of the accumulation, over time, of organic matter that leads to an anaerobic environment reducing microbial activity, decelerating decomposition, and generation of nutrient-poor microsites for regeneration with significant impacts on site productivity. In a large field study conducted in northwestern Quebec (Canada), Henneb et al. [17] verified how various intensities of mechanical site preparation interacted with site characteristics to influence the availability of microsites conducive to reforestation, initial planted seedling growth, and abundance of key competing shrub species. According to their findings, mechanical site preparation is effective in creating conditions that allow for the successful regeneration of paludified sites. However, their results showed that successful seedling establishment requires distinguishing slightly/moderately paludified conditions from highly paludified conditions when prescribing the appropriate mechanical site preparation treatment, as treatments interacted with an initial organic layer thickness in driving microsite, seedling, and vegetation responses. 


\section{Concluding Remarks}

The changing climate and its associated uncertainty require silviculture to evolve as an advanced observational, anticipative, and adaptive discipline [18]. The collection of papers found in this Special Issue provides a few examples of experiments that enable developing adaptive silviculture strategies so that forests can maintain the provision of ecosystem services under a changing environment. Either by reporting about the testing of new, innovative treatments or about results from the monitoring of existing mid- to long-term trials, these papers offer an interesting perspective on the breadth of current silviculture research in the northern hemisphere.

Author Contributions: Conceptualization, N.T. and B.D.P.; writing-original draft preparation, N.T.; writing - review and editing, B.D.P. All authors have read and agreed to the published version of the manuscript.

Funding: This research received no external funding.

Institutional Review Board Statement: Not applicable.

Informed Consent Statement: Not applicable.

Data Availability Statement: Not applicable.

Conflicts of Interest: The authors declare no conflict of interest.

\section{References}

1. Trumbore, S.; Brando, P.; Hartmann, H. Forest health and global change. Science 2015, 349, 814-818. [CrossRef] [PubMed]

2. Gauthier, S.; Bernier, P.; Kuuluvainen, T.; Shvidenko, A.Z.; Schepaschenko, D.G. Boreal forest health and global change. Science 2015, 349, 819-822. [CrossRef] [PubMed]

3. Anderegg, W.R.L.; Trugman, A.T.; Badgley, G.; Anderson, C.M.; Bartuska, A.; Ciais, P.; Cullenward, D.; Field, C.B.; Freeman, J.; Goetz, S.J.; et al. Climate-driven risks to the climate mitigation potential of forests. Science 2020, 368, eaaz7005. [CrossRef] [PubMed]

4. Canadian Council of Forest Ministers Innovation Committee. A Forest Bioeconomy Framework for Canada; Natural Resources Canada: Ottawa, ON, Canada, 2017; p. 29.

5. Nyland, R.D.; Kenefic, L.S.; Bohn, K.K.; Stout, S.L. Silviculture: Concepts and Applications, 3rd ed.; Waveland Press, Inc.: Long Grove, IL, USA, 2016; p. 680.

6. Royer-Tardif, S.; Bauhus, J.; Doyon, F.; Nolet, P.; Thiffault, N.; Aubin, I. Revisiting the functional zoning concept under climate change to expand the portfolio of adaptation options. Forests 2021, 12, 273. [CrossRef]

7. Millar, C.I.; Stephenson, N.L.; Stephens, S.L. Change and forests of the future: Managing in the face of uncertainty. Ecol. Appl. 2007, 17, 2145-2151. [CrossRef] [PubMed]

8. Nagel, L.M.; Palik, B.J.; Battaglia, M.A.; D’Amato, A.W.; Guldin, J.M.; Swanston, C.W.; Janowiak, M.K.; Powers, M.P.; Joyce, L.A.; Millar, C.I.; et al. Adaptive silviculture for climate change: A national experiment in manager-scientist partnerships to apply an adaptation framework. J. For. 2017, 115, 167-178. [CrossRef]

9. Sloan, J.L.; Salifu, F.K.; Jacobs, D.F. Nitrogen recovery from enhanced efficiency fertilizers and urea in intensively managed black walnut (Juglans nigra) plantations. Forests 2021, 12, 352. [CrossRef]

10. Skovsgaard, J.P.; Johansson, U.; Holmström, E.; Tune, R.M.; Ols, C.; Attocchi, G. Effects of thinning practice, high pruning and slash management on crop tree and stand growth in young even-aged stands of planted silver birch (Betula pendula Roth). Forests 2021, 12, 225. [CrossRef]

11. Maleki, K.; Nguema Allogo, F.; Lafleur, B. Natural regeneration following partial and clear-cut harvesting in mature aspen-jack pine stands in eastern Canada. Forests 2020, 11, 741. [CrossRef]

12. Royo, A.A.; Pinchot, C.C.; Stanovick, J.S.; Stout, S.L. Timing is not everything: Assessing the efficacy of pre- versus post-harvest herbicide applications in mitigating the burgeoning birch phenomenon in regenerating hardwood stands. Forests 2019, 10, 324. [CrossRef]

13. Pinno, B.D.; Hossain, K.L.; Gooding, T.; Lieffers, V.J. Opportunities and challenges for intensive silviculture in Alberta, Canada. Forests 2021, 12, 791. [CrossRef]

14. Deighton, H.D.; Bell, F.W.; Thiffault, N.; Searle, E.B.; Leitch, M.; Sharma, M.; Dacosta, J. Trade-offs among release treatments in jack pine plantations: Twenty-five year responses. Forests 2021, 12, 370. [CrossRef]

15. de Vriendt, L.; Thiffault, N.; Royo, A.A.; Barrette, M.; Tremblay, J.P. Moose browsing tends spruce plantations more efficiently than a single mechanical release. Forests 2020, 11, 1138. [CrossRef]

16. Ménard, L.-P.; Ruel, J.-C.; Thiffault, N. Abundance and impacts of competing species on conifer regeneration following careful logging in the eastern Canadian boreal forest. Forests 2019, 10, 177. [CrossRef] 
17. Henneb, M.; Valeria, O.; Thiffault, N.; Fenton, N.J.; Bergeron, Y. Effects of mechanical site preparation on microsite availability and growth of planted black spruce in Canadian paludified forests. Forests 2019, 10, 670. [CrossRef]

18. Achim, A.; Moreau, G.; Coops, N.C.; Axelson, J.N.; Barrette, J.; Bédard, S.; Byrne, K.E.; Caspersen, J.; Dick, A.R.; D’Orangeville, L.; et al. The changing culture of silviculture. Forestry 2021, in press. 